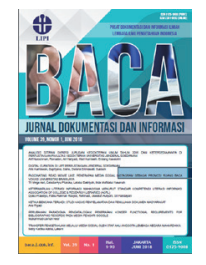

\title{
Peran perpustakaan perguruan tinggi dalam mendukung implementasi Sustainable Development Goals 4
}

\author{
Elvy Suprianingrum ${ }^{1 *} ;$ Heriyanto $^{2}$ \\ ${ }^{1,2}$ Universitas Diponegoro, Indonesia \\ *Korespondensi: elvysuprianingrum22@gmail.com
}

Diajukan: 23-12-2021; Direview: 26-01-2021; Diterima: 21-04-2021; Direvisi: 31-05-2021

\begin{abstract}
This study aims to identify the role of academic libraries in supporting the implementation of SDGs 4. The research method employed was the qualitative method using semi-structured interviews for data collection. The collected data then analyzed using thematic analysis, qualitative data analysis for identifying patterns throughout the data. Two themes that emerged are Programs and Challenges. The Program's theme explains the role of the libraries to support the implementation of SDGs 4. It explains the providing access to information for users, the library cooperation programs with other parties who also take part in supporting the implementation of SDGs 4, and the training programs to develop human resources. The challenge's theme illustrates the activities or the policies in libraries that can hamper the libraries to support the implementation of SDGs 4. This research benefit university libraries in providing insights about how to support the implementation of SDGs 4.
\end{abstract}

\begin{abstract}
ABSTRAK
Penelitian ini bertujuan untuk mengidentifikasi peran perpustakaan perguruan tinggi dalam mendukung implementasi SDGs 4 . Metode penelitian yang digunakan adalah metode kualitatif dengan menggunakan wawancara semiterstruktur sebagai teknik pengumpulan data. Data yang terkumpul kemudian dianalisis menggunakan thematic analysis. Hasil analisis menunjukkan dua tema, yaitu program dan kendala. Tema program menjelaskan tentang peran yang perpustakaan lakukan untuk mendukung implementasi SDGs 4. Tema ini menceritakan tentang penyediaan akses informasi kepada pemustaka, program kerja sama perpustakaan dengan pihak-pihak lain yang juga turut andil dalam mendukung implementasi SDGs 4, serta program pelatihan untuk mengembangkan sumber daya manusia. Tema kendala mengilustrasikan tentang kegiatan atau kebijakan yang ada di perpustakaan yang dapat menghambat perpustakaan dalam memberikan dukungan dalam implementasi SDGs 4. Penelitian ini berkontribusi dalam memberikan pengetahuan baru bagaimana perpustakaan berperan dalam mendukung implementasi Sustainable Development Goal 4.
\end{abstract}

Keywords: Academic library; Library roles; Sustainable development goals; Information access

\section{PENDAHULUAN}

Sustainable Development Goals (SDGs) atau Tujuan Pembangunan Berkelanjutan merupakan kesepakatan global dalam pembangunan berkelanjutan yang memastikan tidak ada satu warga negara pun yang tertinggal (No One Left Behind) sesuai hak asasinya. Kesepakatan global ini juga menjunjung prinsip universal, integral, dan inklusif (Kementerian PPN/Bappenas, 2017). Sustainable Development Goals memiliki 17 tujuan yang mencakup hampir semua aspek kehidupan, salah satunya yaitu meningkatkan kualitas pendidikan (SDGs 4).

Perguruan tinggi sebagai lembaga pendidikan yang memiliki kontribusi luas dalam bidang pendidikan bertanggung jawab atas melaksanakan tujuan SDGs 4 yaitu meningkatkan kualitas pendidikan. Salah satu unit di perguruan tinggi yang berperan dalam menyediakan layanan ilmu pengetahuan yaitu perpustakaan. Pada tahun 2016 International Federation of Library Association and Institutional (IFLA) telah menerbitkan booklet yang berjudul "Libraries Can Drive Progress Across the Entire UN 2030 Agenda", yang berisi beberapa peran perpustakaan dalam mendukung 
SDGs 4 yaitu dengan menyediakan staf berdedikasi untuk mendukung literasi dan pembelajaran seumur hidup, menyediakan akses informasi dan penelitian untuk siswa, menyediakan ruang inklusif, di mana biaya tidak menjadi penghalang untuk memperoleh pengetahuan baru (IFLA, 2016).

Keterlibatan perpustakaan dalam pewujudan SDGs disampaikan oleh Maria \& Chinemerem (2019) bahwa perpustakaan sebagai pusat akademik sangat diperlukan dalam penyediaan informasi untuk dapat mendukung tujuan pembangunan berkelanjutan. Hasil penelitian menunjukkan bahwa perpustakaan berperan dalam implementasi SDGs 4 melalui kegiatan promosi ke masyarakat luas untuk menggunakan sumber daya dan layanan perpustakaan sebagai platform pendukung SDGs. Perpustakaan memiliki peran yang cukup vital dalam program-program pembangunan berkelanjutan (IFLA, 2015).

Pencapaian tujuan SDGs 4 ini perlu melibatkan pihak-pihak yang secara langsung berkontribusi dalam pembelajaran dan meningkatkan mutu pendidikan, salah satu pihak tersebut adalah perpustakaan. Salah satu fungsi dari perpustakaan perguruan tinggi adalah menjadi perpustakaan sebagai tempat pembelajaran seumur hidup (Anday, 2006). Penelitian ini membahas tentang peran perpustakaan perguruan tinggi di Indonesia dalam mendukung program SDGs 4. Penelitian ini melibatkan 4 perpustakaan perguruan tinggi yaitu Perpustakaan Universitas Diponegoro, Perpustakaan Universitas Airlangga, Perpustakaan Universitas Gadjah Mada, dan Perpustakaan Universitas Indonesia. Penelitian ini penting dilakukan untuk menginvestigasi berbagai upaya dan pengalaman perpustakaan perguruan tinggi di Indonesia dalam mewujudkan tujuan SDGs 4.

\section{TINJAUAN PUSTAKA}

\subsection{Sustainable Development Goals (SDGs)}

SDGs merupakan suatu agenda untuk pembangunan berkelanjutan yang dijalankan oleh semua negara anggota PBB pada tahun 2015. Agenda global ini memiliki 17 tujuan, 169 target, dan 241 indikator. Tujuh belas tujuan tersebut saling berhubungan dan dilaksanakan secara merata tanpa meninggalkan seorangpun. Hal ini dilakukan untuk mengatasi tentang masalah global yang dihadapi hampir di setiap negara termasuk yang terkait dengan kemiskinan, kesenjangan, perubahan iklim, masalah lingkungan, perdamaian dan keadilan.

SDGs di Indonesia diatur dalam Peraturan Presiden Nomor 59 Tahun 2017 tentang Pelaksanaan Pencapaian Tujuan Pembangunan Berkelanjutan. Peraturan tersebut sebagai bentuk komitmen pemerintah dalam melaksanakan SDGs yang telah ditandatangani oleh Presiden Jokowi. 17 tujuan tersebut meliputi sebagai berikut;

- Tujuan 01: mengentaskan kemiskinan (mengurangi kemiskinan di manapun dan dalam semua bentuk).

- Tujuan 02: mengakhiri kelaparan (mengakhiri kelaparan, mencapai ketahanan pangan dan nutrisi yang lebih baik dan mendukung pertanian berkelanjutan).

- Tujuan 03: kesehatan yang baik dan kesejahteraan (memastikan kehidupan yang sehat dan mendukung kesejahteraan bagi semua usia).

- Tujuan 04: pendidikan bermutu (memastikan pendidikan yang inklusif dan berkualitas setara, juga mendukung kesempatan belajar seumur hidup bagi semua).

- Tujuan 05: kesetaraan gender (mencapai kesetaraan gender dan memberdayakan semua perempuan dan anak perempuan).

- Tujuan 06: Akses air bersih dan sanitasi (memastikan ketersediaan dan manajemen air bersih yang berkelanjutan dan sanitasi bagi semua).

- Tujuan 07: energi bersih dan terjangkau (memastikan akses terhadap energi terjangkau, dapat diandalkan, berkelanjutan dan modern bagi semua). 
- Tujuan 08: pekerjaan layak dan pertumbuhan ekonomi (mendukung pertumbuhan ekonomi yang inklusif dan berkelanjutan, tenaga kerja penuh dan produktif dan pekerjaan yang layak bagi semua).

- Tujuan 09: infrastruktur, industri, dan inovasi (membangun infrastruktur yang tahan lama, mendukung industrialisasi yang inklusif dan berkelanjutan dan membantu perkembangan inovasi).

- Tujuan 10: mengurangi ketimpangan (mengurangi ketimpangan di dalam dan antar negara).

- Tujuan 11: kota dan komunitas yang berkelanjutan (membangun kota dan pemukiman inklusif, aman, tahan lama, dan berkelanjutan).

- Tujuan 12: konsumsi dan produksi yang bertanggung jawab (memastikan pola konsumsi dan produksi berkelanjutan).

- Tujuan 13: penanganan perubahan iklim (mengambil aksi segera untuk memerangi perubahan iklim dan dampaknya).

- Tujuan 14: menjaga ekosistem laut (mengonservasi dan memanfaatkan secara berkelanjutan sumber daya laut, samudera, dan maritim untuk pembangunan berkelanjutan).

- Tujuan 15: menjaga ekosistem darat (melindungi, memulihkan, dan mendukung penggunaan yang berkelanjutan terhadap ekosistem daratan, mengelola hutan secara berkelanjutan, memerangi desertifikasi, menghambat dan mengembalikan degradasi tanah dan menghambat hilangnya keanekaragaman hayati).

- Tujuan 16: perdamaian, keadilan, dan kelembagaan yang kuat (mendukung masyarakat yang damai dan inklusif untuk pembangunan berkelanjutan, menyediakan akses terhadap keadilan bagi semua dan membangun institusi-institusi yang efektif, akuntabel dan inklusif di semua level).

- Tujuan 17: Kemitraan untuk mencapai tujuan (menguatkan ukuran implementasi dan merevitalisasi kemitraan global untuk pembangunan yang berkelanjutan (Kementerian PPN/Bappenas, 2017).

SDGs dicanangkan hingga tahun 2030. Agenda SDGs ini merupakan penyempurnaan dari agenda Millennium Development Goals (MDGs) yang telah berakhir pada tahun 2015.

\subsection{Peran Perpustakaan dalam Mendukung SDGs 4}

IFLA telah mengadvokasi program perpustakaan di setiap negara untuk berperan aktif dalam mendukung pelaksanaan SDGs 4. IFLA mengeluarkan toolkit dan booklet terkait beberapa kontribusi perpustakaan dalam mendukung pencapaian tujuan SDGs. Tabel 1 merupakan kegiatan perpustakaan dalam mendukung Program SDGs 4 menurut IFLA (2016).

Tabel 1. Program Perpustakaan Mengacu pada Tujuan SDGs 4

\begin{tabular}{lc}
\hline Tujuan SDGs & Peran Perpustakaan \\
\hline Goal 1: Mengakhiri kemiskinan & Perpustakaan dapat mendukung tujuan ini dengan menyediakan: \\
dalam segala bentuk di manapun & - Akses publik ke informasi dan sumber daya yang memberi orang \\
& peluang untuk meningkatkan kehidupan mereka. \\
& - Pelatihan keterampilan baru yang dibutuhkan untuk pendidikan dan \\
& pekerjaan. \\
& Informasi untuk mendukung pengambilan keputusan oleh pemerintah, \\
& masyarakat sipil, dan bisnis untuk memerangi kemiskinan. \\
\hline
\end{tabular}




\begin{tabular}{l}
\hline Tujuan SDGs \\
\hline Goal 2: Menghilangkan kelaparan, \\
mencapai ketahanan pangan dan \\
gizi yang baik, serta meningkatkan \\
pertanian berkelanjutan
\end{tabular}

Peran Perpustakaan

Perpustakaan dapat mendukung tujuan ini dengan menyediakan:

- Penelitian tentang pertanian dan data tentang bagaimana membuat tanaman lebih produktif dan berkelanjutan.

- Akses publik untuk petani ke sumber daya online seperti harga pasar lokal, laporan cuaca, dan peralatan baru.

Goal 3: Menjamin kehidupan yang sehat dan meningkatkan kesejahteraan seluruh penduduk semua usia

Perpustakaan dapat mendukung tujuan ini dengan menyediakan:

- Penelitian tersedia di perpustakaan medis dan rumah sakit yang mendukung pendidikan dan meningkatkan praktik medis untuk penyedia layanan kesehatan.

- Akses informasi ke publik tentang kesehatan dan kebugaran di perpustakaan umum yang membantu individu dan keluarga tetap sehat.

Goal 4: Menjamin kualitas pendidikan yang inklusif dan merata serta meningkatkan kesempatan belajar sepanjang hayat untuk semua

Perpustakaan dapat mendukung tujuan ini dengan menyediakan:

- Staf berdedikasi yang mendukung literasi dini dan pembelajaran seumur hidup.

- Akses untuk informasi dan penelitian untuk siswa di manapun.

- Ruang inklusif di mana biaya tidak menjadi penghalang bagi pemustaka untuk memperoleh pengetahuan dan keterampilan baru.

Goal 5: Mencapai kesetaraan gender dan memberdayakan kaum perempuan

Perpustakaan dapat mendukung tujuan ini dengan menyediakan:

- Ruang aman dan pelayanan yang baik.
- Program dan layanan yang dirancang untuk memenuhi kebutuhan perempuan dan anak perempuan, seperti hak dan kesetaraan.

- Akses untuk informasi dan TIK yang membantu wanita membangun keterampilan bisnis.

Goal 6: Menjamin ketersediaan serta pengelolaan air bersih dan sanitasi yang berkelanjutan untuk semua

Perpustakaan dapat mendukung tujuan ini dengan menyediakan:

- Akses informasi berkualitas dan praktik-praktik baik yang mendukung proyek pengelolaan air dan sanitasi setempat.

- Akses gratis yang dapat diandalkan untuk listrik dan cahaya untuk membaca, belajar, dan bekerja.

Goal 8: Meningkatkan pertumbuhan ekonomi yang inklusif dan berkelanjutan, kesempatan kerja yang produktif dan menyeluruh, serta pekerjaan yang layak untuk semua

Goal 9: Membangun infrastruktur yang tangguh, meningkatkan industri inklusif dan berkelanjutan, serta mendorong inovasi
Perpustakaan dapat mendukung tujuan ini dengan menyediakan akses informasi dan pelatihan keterampilan yang orang perlu temukan, melamar, dan berhasil dalam pekerjaan yang lebih baik.

Perpustakaan dapat mendukung tujuan ini dengan menyediakan:

- Memperluas infrastruktur yang ada dari perpustakaan umum dalam hal penelitian dan tenaga profesional perpustakaan yang terampil.

- Ruang publik yang ramah dan inklusif.

- Menyediakan akses TIK seperti internet berkecepatan tinggi yang mungkin tidak tersedia di tempat lain. 


\begin{tabular}{ll}
\hline Tujuan SDGs & Peran Perpustakaan \\
\hline Goal 10: Mengurangi kesenjangan & Perpustakaan dapat mendukung tujuan ini dengan menyediakan: \\
intra dan antar negara & Perpustakaan netral dan ramah yang membuat pembelajaran dapat \\
& diakses oleh semua, termasuk kelompok-kelompok yang terping- \\
& girkan seperti imigran, pengungsi, minoritas, masyarakat adat, dan \\
& para penyandang disabilitas. \\
& Akses yang dapat diakses ke informasi yang mendukung inklusi \\
& sosial, politik, dan ekonomi. \\
\hline
\end{tabular}

Goal 11: Menjadikan kota dan pemukiman kota dan pemukiman inklusif, aman, tangguh dan berkelanjutan

Goal 12: Menjamin pola produksi dan konsumsi yang berkelanjutan

Goal 13: Mengambil tindakan cepat untuk mengatasi perubahan iklim dan dampaknya

Goal 14: Melestarikan dan memanfaatkan secara berkelanjutan sumber daya kelautan dan samudera untuk pembangunan berkelanjutan

Goal 15: Melindungi, merestorasi dan meningkatkan pemanfaatan berkelanjutan ekosistem darat, mengelola hutan secara lestari, menghentikan memulihkan degradasi lahan, serta menghentikan kehilangan keanekaragaman hayati

Goal 16: Menguatkan masyarakat yang inklusif dan damai untuk perkembangan berkelanjutan, menyediakan akses keadilan untuk semua dan membangun kelembagaan yang efektif, akuntabel, dan inklusif di semua tingkatan

Goal 17: Menguatkan sarana pelaksanaan dan merevitalisasi kemitraan global untuk pembangunan berkelanjutan
Perpustakaan dapat mendukung tujuan ini dengan menyediakan:

- Lembaga-lembaga terpercaya yang didedikasikan untuk mempromosikan inklusi dan pemahaman budaya.

- Dokumentasi dan pelestarian warisan budaya untuk generasi mendatang.

Perpustakaan dapat mendukung tujuan ini dengan menyediakan:

- Berbagi sistem yang berkelanjutan dan mengedarkan bahan-bahan yang mengurangi limbah.

- Catatan sejarah tentang pesisir dan penggunaan lahan.

- Penelitian dan data yang diperlukan untuk menginformasikan kebijakan perubahan iklim.

- Akses informasi yang luas yang diperlukan untuk memandu pengambilan keputusan oleh pemerintah daerah dan nasional untuk topik-topik seperti berburu, memancing, penggunaan lahan, dan pengelolaan air.
Perpustakaan dapat mendukung tujuan ini dengan menyediakan:

- Akses publik ke informasi tentang pemerintah, masyarakat sipil, dan lembaga lainnya.

- Pelatihan dalam keterampilan yang dibutuhkan untuk memahami dan menuntut informasi ini.

- Ruang inklusif, netral, dan unsur politik bagi orang untuk bertemu dan berorganisasi.

Perpustakaan dapat mendukung tujuan ini dengan menyediakan jaringan global lembaga berbasis masyarakat, siap untuk mendukung rencana pembangunan lokal.

Sumber: IFLA (2016)

Peran perguruan tinggi dalam pendidikan adalah memberikan pengetahuan dan solusi baru untuk mendukung tujuan SDGs. Perguruan tinggi memegang kendali dalam kemajuan teknologi dan masyarakat melalui penelitian, penemuan, dan penciptaan pengetahuan. Fokus pendidikan program SDGs 4 yaitu menciptakan pendidikan yang berkualitas, dengan meningkatnya kualitas 
pendidikan dapat mengarah ke hasil pembangunan yang lebih baik bagi individu dan masyarakat (Sustainable Development Solutions Network (SDSN)-Australia/Pacific in collaboration with the Australasian Campuses Towards Sustainability (ACTS) and the global SDSN Secretariat, 2017). Perpustakaan dapat membantu pencapaian tujuan SDGs 4 untuk meningkatkan mutu pendidikan.

\subsection{Penelitian Terdahulu}

Penelitian Maria \& Chinemerem (2019) yang berjudul "Ensure Inclusive and Equitable Quality Education and Promote Lifelong Learning Opportunities for Achieving Sustainable Development Goals: The Role of Libraries", bertujuan untuk mempromosikan peran perpustakaan dalam pembangunan berkelanjutan yang berfokus pada kualitas pendidikan, karena perpustakaan sebagai pusat kegiatan akademik dan informasi masyarakat. Metode penelitian kualitatif dengan studi literatur digunakan dalam penelitian tersebut. Hasil penelitian menunjukkan bahwa: (a) perpustakaan harus memahami bahwa sangat diperlukan dalam penyediaan informasi untuk pencapaian SDGs; (b) pustakawan dan perpustakaan perlu dukungan organisasi induk dengan semua fasilitas yang diperlukan dan dukungan keuangan sehingga pustakawan dapat menghadiri seminar profesional dan lokakarya untuk pemberian layanan yang efektif dalam mendukung pencapaian SDGs; (c) jumlah staf yang memadai dalam hal jumlah dan kualifikasi profesional perlu diperhatikan; (d) perpustakaan harus berusaha keras untuk memperoleh informasi tentang SDGs dan mengedukasi pemustaka tentang SDGs; (e) pustakawan perlu lebih teliti dalam pelayanan yang berdampak pada pencapaian SDGs, melalui pengorganisasian program kesadaran, forum lokal, bekerja sama dengan lembaga lain.

Penelitian Samantaray (2017) yang berjudul "Role of Libraries in Quality Education for Achieving $S D G$ ", bertujuan untuk mengetahui tentang peran perpustakaan dalam menunjang SDGs melalui upaya menjadikan perpustakaan sebagai pusat pengetahuan untuk memperhatikan terkait literasi informasi masyarakat. Metode penelitian yang digunakan adalah kualitatif, yang bersumber dari studi pustaka. Hasil penelitian menunjukkan bahwa administrator, pembuat kebijakan, manajer, sarjana, peneliti dan anggota masyarakat untuk menggunakan sumber daya dan layanan perpustakaan sebagai rencana kerja dalam menunjang SDGs.

Penelitian Ezeani et al. (2017) yang berjudul “Towards Sustainable Development Goals: What Role for Academic Libraries in Nigeria in Assuring Inclusive Access to Information for Learners with Special Needs?", bertujuan untuk mengetahui layanan perpustakaan dalam memenuhi kebutuhan mahasiswa yang berkebutuhan khusus melalui akses pendidikan yang berkualitas dan inklusif guna tercapainya pembangunan berkelanjutan. Metode penelitian kualitatif ini bersumber dari kegiatan observasi yang dilakukan oleh enam mahasiswa tunanetra dari universitas yang ada di Nigeria. Hasil dari penelitian menunjukkan bahwa perpustakaan dapat mendukung pencapaian SDGs dalam sektor pendidikan yang inklusif melalui penyediaan akses informasi yang adil, dan perpustakaan perlu menyediakan layanan yang lengkap dan pustakawan yang kompeten di bidangnya.

Penelitian Mansour (2019) yang berjudul "Libraries as Agents for Development: The Potential Role of Egyptian Rural Public Libraries Towards the Attainment of Sustainable Development Goals based on the UN 2030 Agenda", bertujuan untuk mengetahui peran perpustakaan umum di Mesir yang menjadi agen SDGs. Hasil penelitian menunjukkan bahwa perpustakaan umum di Mesir telah berperan aktif dalam mendukung implementasi SDGs melalui integrasi dan adaptasi program pendidikan perpustakaan dengan masyarakat sekitar.

Penelitian Okuonghae \& Igbinovia (2019) yang berjudul "The Role of Academic Libraries towards the Attainment of Sustainable Development Goals: The Nigerian Perspective”, bertujuan untuk mengetahui peran perpustakaan akademik dalam mendukung agenda SDGs di Nigeria. Metode penelitian yang digunakan adalah kuantitatif, dengan menggunakan 270 sampel dari perpustakaan akademik di Nigeria. Hasil penelitian menunjukkan bahwa perpustakaan akademik berkontribusi dalam aktualisasi SDGs di Nigeria melalui layanan pembelajaran yang kondusif, sumber daya ruang dan informasi untuk pengguna. 


\section{METODE}

Penelitian ini dilakukan secara kualitatif untuk mengidentifikasi peran perpustakaan perguruan tinggi dalam mendukung implementasi SDGs 4. Penelitian kualitatif adalah metode ilmiah yang digunakan untuk menjelaskan suatu fenomena dengan cara deskriptif dan berdasarkan pada pengalaman seseorang yang terlibat didalam fenomena tersebut (Silverman, 2016). Untuk merekrut pustakawan sebagai partisipan, diawal penelitian telah dibuat beberapa kriteria sampling yang relevan dengan tujuan penelitian. Teknik ini disebut juga sebagai teknik purposive sampling (Cohen, Manion, \& Morrison 2007), sebuah teknik perekrutan partisipan untuk penelitian dengan mengutamakan individu-individu yang memiliki pengetahuan dan pengalaman mengenai obyek yang sedang diteliti (Palinkas et al, 2015). Kriteria partisipan yaitu pustakawan perpustakaan perguruan tinggi dan terlibat dalam kegiatan dan layanan perpustakaan yang mengacu pada SDGs 4. Melalui satu pustakawan yang bersedia berpartisipasi, peneliti direkomendasikan untuk menghubungi pustakawan lain yang layanan perpustakaannya mengacu pada SDGs 4. Total pustakawan yang berpartisipasi dalam penelitian ini sebanyak 4 orang, yaitu pustakawan Perpustakaan Universitas Indonesia, Universitas Diponegoro, Universitas Airlangga, dan Universitas Gadjah Mada. Seluruh pustakawan mengikuti wawancara yang dilakukan dengan teknik semi-struktur. Data yang terkumpul, dianalisis menggunakan Thematic analysis, sebuah metode untuk mengidentifikasi dan menganalisis pola atau tema yang dianggap penting untuk menggambarkan fenomena yang sedang diteliti (Heriyanto, 2018). Hasil analisis menjadi dasar penyusunan hasil dan pembahasan.

\section{HASIL DAN PEMBAHASAN}

\subsection{Program Perpustakaan}

Tema program perpustakaan diperoleh dari mengelompokkan tema yang sejenis yaitu program perpustakaan, penyediaan akses informasi, kerja sama, dan pelatihan pengembangan sumber daya manusia. Kelompok tema tersebut dapat didefinisikan menjadi satu tema besar yaitu program perpustakaan sebagai peran dalam mendukung implementasi SDGs 4. Kelompok tema tersebut adalah peran yang dapat dilakukan oleh perpustakaan perguruan tinggi dalam mendukung implementasi SDGs 4.

Kelompok tema pertama yaitu program perpustakaan menjelaskan bahwa setiap perpustakaan memiliki fungsi dan tujuan masing-masing berdasarkan dari lembaga induk yang menaunginya. Perpustakaan dapat mendukung tujuan SDGs 4 yaitu menjamin kualitas pendidikan yang inklusif dan merata serta meningkatkan kesempatan belajar sepanjang hayat untuk semua. Perpustakaan mendukung tujuan SDGs 4 ini dengan cara menyediakan staf berdedikasi yang mendukung literasi dini dan pembelajaran seumur hidup, akses untuk informasi dan penelitian untuk siswa dimanapun dan menyediakan ruang inklusif dimana biaya tidak menjadi penghalang bagi pemustaka untuk memperoleh pengetahuan dan keterampilan baru (IFLA, 2016).

Perpustakaan Universitas Indonesia menyelenggarakan program knowledge-based industry - dengan memberikan pelatihan kepada guru SD, SMP, dan SMA, dan manajemen perpustakaan yang melibatkan masyarakat umum untuk berpartisipasi aktif dalam kegiatan tersebut. Program Perpustakaan Universitas Diponegoro melalui layanan akses informasi e-jurnal. Perpustakaan Universitas Gadjah Mada menyelenggarakan program peminjaman dengan perjanjian yang bertujuan agar pemustaka tetap dapat mengakses sumber informasi tanpa harus datang ke perpustakaan berdasarkan syarat yang berlaku. Perpustakaan Airlangga menyedikan jam layanan lebih lama dalam mendukung tujuan dari SDGs 4. Perbedaan program layanan informasi tersebut dikarenakan setiap perpustakaan memiliki kebijakan dan tujuan pelayanan yang berbeda-beda. 


\subsection{Penyediaan Akses Informasi}

Penyediaan akses informasi terkait dengan kegiatan perpustakaan perguruan tinggi untuk mendukung implementasi program SDGs 4, yaitu menyediakan akses informasi di Perpustakaan Universitas Indonesia, Universitas Diponegoro, Universitas Airlangga, dan Universitas Gadjah Mada. Setiap perpustakaan tersebut menyediakan akses informasi secara online yang dapat dijangkau oleh siapapun secara gratis. Perpustakaan juga menyediakan koleksi bagi penyandang disabilitas beserta akses untuk menggunakan pelayanan tersebut dengan penyediaan ramp dan tangga untuk masuk ke perpustakaan.

Tujuan SDGs 4 adalah meningkatkan kualitas pendidikan yang inklusif dan merata, serta memberikan kesempatan belajar sepanjang hayat untuk semua. Perpustakaan dapat berperan dalam meningkatkan kualitas pendidikan yang inklusif dan merata serta memberikan kesempatan belajar sepanjang hayat untuk semua melalui penyediaan akses informasi seluas-luasnya, dengan menyediakan ruang yang inklusif.

Informan mengatakan bahwa memberikan pelayanan secara inklusif dapat dilakukan dengan cara menyediakan fasilitas bagi penyandang disabilitas. Pendidikan yang inklusif yaitu pendidikan yang harus memberikan akomodasi ke semua anak tanpa memandang dari sisi kondisi fisik, kecerdasan, linguistik, emosional, sosial ataupun kondisi yang lainnya, yang mencakup anak-anak yang memiliki kebutuhan khusus, anak-anak yang berasal dari daerah terpencil, anak-anak yang berasal dari etnis yang minoritas, linguistik, dan budaya serta anak-anak yang berasal dari kelompok yang kurang beruntung atau termajinalisasi (Olsen, 2003).

Praktik perpustakaan berbasis inklusi di perpustakaan dapat dilakukan dengan menyediakan layanan berdasarkan kebutuhan informasi pemustaka, bukan dari latar belakang pendidikan, tingkat ekonomi, jabatan, agama, ras maupun ideologi (Susanti, 2019). Perpustakaan perguruan tinggi berperan dalam mendukung implementasi SDGs 4 melalui layanan informasi secara inklusif dan merata dengan menyediakan fasilitas untuk penyandang disabilitas. Layanan informasi yang disediakan perpustakaan perguruan ditujukan bagi semua mahasiswa termasuk mahasiswa yang memiliki kebutuhan khusus dalam mengakses informasi. Tujuan dari SDGs 4 adalah menciptakan pendidikan berkualitas yang inklusif dan adil, serta promosi kesempatan belajar seumur hidup untuk semua berfokus pada kesetaraan gender dalam pendidikan dan memastikan akses yang sama ke semua tingkat pendidikan dan pelatihan kejuruan bagi mereka yang rentan, termasuk penyandang disabilitas. Tujuan tersebut menyerukan untuk membangun dan meningkatkan fasilitas pendidikan terhadap anak, dan penyandang disabilitas dan juga menyediakan lingkungan belajar yang aman, tanpa kekerasan, inklusif, dan efektif untuk semua (United-Nations, 2015).

\subsection{Kerja sama}

Tema kerja sama menjelaskan peran perpustakaan perguruan tinggi dalam mendukung tercapainya program SDGs 4 melalui kegiatan bermitra dengan lembaga atau pihak lain dengan tujuan meningkatkan kualitas layanan. Informan mengatakan bahwa perpustakaan tidak dapat menyediakan layanan informasi secara komprehensif tanpa bekerja sama dengan pihak lain. Kerja sama yang dilakukan perpustakaan perguruan tinggi berorientasi pada peningkatan kualitas pendidikan yang inklusif dan merata serta meningkatkan kesempatan belajar sepanjang hayat untuk semua sivitas akademika.

Susanti (2019) dalam Britain (1999) menjelaskan bahwa perpustakaan menjalin kerja sama yang baik dengan komunitas pembelajar di berbagai kalangan dalam mendukung terbentuknya life long learner. Perpustakaan perguruan tinggi harus membuka diri untuk berbagai jenis kerja sama, baik dari perguruan tinggi lain maupun dengan komunitas pembelajar yang membutuhkan akses informasi. Kerja sama yang terjalin memiliki program tertentu yang bertujuan untuk mengembangkan 
dan meningkatkan kualitas dari berbagai pihak yang terikat dalam kerja sama. Program kerja sama ini dapat berupa kegiatan pelatihan dan pengembangan sumberdaya manusia.

Bentuk kerja sama Perpustakaan Universitas Indonesia yaitu memberikan pelatihan pengembangan sumberdaya manusia dengan melibatkan masyarakat sekitar kampus, berupa pelatihan edukasi, kesehatan, dan ekonomi. Kerja sama ini dilakukan dengan berbagai pihak selain perpustakaan yang memiliki program SDGs 4. IFLA (2016) menyatakan bahwa perpustakaan dapat berperan dalam mendukung program SDGs 4 melalui penyediaan ruang inklusif untuk memperoleh pengetahuan baru.

Kerja sama Perpustakaan Universitas Airlangga dengan pihak lain bertujuan untuk mengembangkan perpustakaan, pustakawan, dan pemustakanya. Beberapa kerja sama yang sudah dilakukan dengan pihak lain diantaranya dengan FKP2TN (Forum Kerja sama Perpustakaan Perguruan Tinggi Negeri), FPPTI (Forum Perpustakaan Perguruan Tinggi Indonesia), dan Aunilo. Perpustakaan Universitas Airlangga dengan FKP2TN dan FPPTI bertujuan untuk memberikan akses kepada pemustaka di luar kampus untuk memperoleh kartu sakti dan kartu super. Kerja sama lainnya yaitu mengembangkan sumberdaya manusia dari setiap anggota melalui workshop, pelatihan, dan magang. Kerja sama yang dilakukan perpustakaan diharapkan mampu menyediakan ruang yang inklusif kepada pemustaka tanpa terhalang biaya. IFLA (2016) menyatakan bahwa perpustakaan berperan penting dalam mendukung program SDGs 4 melalui penyediaan ruang belajar inklusif untuk memperoleh pengetahuan dan keterampilan tanpa terhalang oleh biaya.

Kerja sama pengembangan sumberdaya manusia diperlukan untuk meningkatkan kualitas layanan perpustakaan, seperti kerja sama yang dilakukan oleh Perpustakaan Universitas Gadjah Mada bekerja sama dengan BLBI (Balai Literasi Braille Indonesia). Kerja sama ini berupa pelatihan kepada pustakawan untuk memberikan pelayanan kepada pengguna penyandang disabilitas. Informan mengatakan bahwa masing-masing perpustakaan berperan dalam mendukung implementasi SDGs 4 melalui program kerja sama dengan berbagai pihak. Kerja sama dalam bentuk penyediaan staf yang kompeten untuk mendukung literasi informasi dan pembelajaran seumur hidup, menyediakan akses informasi untuk keperluan penelitian akademik (mahasiswa dan dosen) - sehingga mereka memperoleh pengetahuan baru dengan mudah. Perpustakaan perguruan tinggi bersedia menjalin kerja sama dengan berbagai komunitas pembelajar untuk mewujudkan generasi long life learner.

\subsection{Pelatihan Pengembangan Sumber Daya Manusia}

Pelatihan pengembangan sumberdaya manusia di perpustakaan tidak hanya ditujukan untuk pustakawan, tetapi juga pemustaka dan masyarakat umum. Kegiatan pelatihan masuk program SDGs 4. Program pelatihan untuk pemustaka dan pustakawan menjadi upaya perpustakaan untuk memberikan pengetahuan baru. Perpustakaan Universitas Indonesia telah melakukan pelatihan bagi guru sekolah (SD, SMP, dan SMA) dan masyarakat umum. Salah satu informan mengatakan bahwa 'setiap tahun perpustakaan menyelenggarakan kegiatan pengabdian masyarakat berupa pelatihan bagi guru SD, SMP, dan SMA terkait manajemen perpustakaan-pelatihan tersebut masuk kegiatan Knowledge Based Industry yang memungkinkan masyarakat umum dapat berpartisipasi dalam berbagai kegiatan".

Perpustakaan Universitas Gadjah Mada, menyelenggarakan program pelatihan pengembangan sumberdaya manusia melalui pelayanan pemustaka yang berkebutuhan khusus. Sebagaimana yang dikatakan informan berikut ini.

"Perpustakaan menyelenggarakan pelatihan bagi staf, tentang bagaimana melayani mahasiswa yang berkebutuhan khusus agar bisa membaca huruf braille, dan mungkin yang berkebutuhan khusus lainya". 
Melalui program pelatihan, informan mengaku memperoleh pengetahuan dan keterampilan baru, yang berguna untuk memaksimalkan layanan kepada pemustaka. Sebagaimana yang dikatakan informan berikut ini.

"Program yang dilakukan perpustakaan setiap tahun berguna untuk pengembangan pengetahuan baru pustakawan. Kegiatan pelatihan perlu dijadwalkan kembali sesuai dengan anggaran perpustakaan yang sudah ada"

Kegiatan pelatihan yang diselenggarakan perpustakaan bervariasi jenisnya, seperti pelatihan penyusunan angka kredit pustakawan. Perpustakaan juga dapat mengusulkan program lain terkait SDGs untuk mengedukasi pemustaka. Layanan informasi dan pembelajaran yang berkualitas di perpustakaan perguruan tinggi mampu memberikan kontribusi untuk aktualisasi SDGs (Emezie \& Igwe, 2017).

\subsection{Kendala Perpustakaan}

Kendala merupakan tema kedua perpustakaan terkait kegiatan dan kebijakan yang mendukung program SDGs 4. Kendala merupakan hal-hal yang menghambat perpustakaan dalam mencapai tujuannya, yang berasal dari faktor internal dan eksternal. Kendala dari internal seperti kebijakan perpustakaan sangat terkait dengan kebijakan lembaga lembaga induknya. Selain kebijakan, kendala lain dalam implementasi program SDGs 4 di perpustakaan yaitu sumberdaya manusia sebagai penggerak tercapainya tujuan perpustakaan. Kendala dari eksternal berupa pandemi Covid-19 yang mempengaruhi kesinambungan layanan perpustakaan. Perpustakaan Universitas Indonesia mengalami kendala kesiapan perpustakaan dalam menyediakan layanan publik seluas mungkin sebagaimana tujuan dari SDGs 4. Perpustakaan Universitas Diponegoro mengalami kendala kurangnya anggaran untuk melaksanakan program perpustakaan. Perpustakaan Airlangga mengalami kendala pada kebijakan perpustakaan yang belum sesuai keinginan pemustaka, misalnya seperti jam buka layanan perpustakaan. Perpustakaan Universitas Gadjah Mada mengalami kendala kurangnya sumberdaya manusia untuk melaksanakan program SDGs 4.

\section{KESIMPULAN}

Perpustakaan perguruan tinggi memiliki peran yang sangat penting dalam mendukung implementasi program SDGs 4. Peran perpustakaan tersebut diimplementasikan melalui penyediaan akses informasi yang terbuka bagi komunitas akademik di perguruan tinggi. Perpustakaan perlu menyelenggarakan program pelatihan bagi mahasiswa dan dosen untuk meningkatkan kompetensi dosen dan mahasiswa, serta menjalin kerja sama dengan berbagai pihak.

\section{DAFTAR PUSTAKA}

Anday, V.G. 2006. The Role of Libraries and Librarians in Information Literacy. In Regional Conference on Promoting Information Literacy for Lifelong Learning, 1-25. Batangas: PLAI-STRLCA.

Cohen, L., Manion, L., \& Morrison, K. 2007. Research Methods in Education. Human Resource Management, 53. Oxon: Routledge. https://doi.org/10.1002/hrm.21698.

Emezie, N.A., \& Igwe, K.N. 2017. Delivery of Community Information Service as Corporate Social Responsibility by Librarians in Nigerian Tertiary Institutions. Information Impact: Journal of Information and Knowledge Management, 8(1): 76-92. https://doi.org/10.4314/iijikm.v8i1.9.

Ezeani, C.N., Ukwoma, S.C., Gani, E., Igwe, P.J., \& Agunwamba, C.G. 2017. Towards Sustainable Development Goals: What Role for Academic Libraries in Nigeria in Assuring Inclusive Access to Information for Learners with Special Needa? IFLA WLIC 2017 Wroclaw, 1-15.

Heriyanto, H. 2018. Thematic Analysis sebagai Metode Menganalisa Data untuk Penelitian Kualitatif. ANUVA, 2(3): 317. https://doi.org/10.14710/anuva.2.3.317-324. 
IFLA, I. 2015. Toolkit: Libraries and Implementation of the UN 2030 Agenda. https://www.ifla.org/files/ assets/hq/topics/libraries-development/documents/libraries-un-2030-agenda-toolkit.pdf.

IFLA, I. 2016. Libraries Can Drive Progress Across the Entire Un 2030 Agenda United Nations Sustainable Development Goals. https://www.ifla.org/files/assets/hq/topics/libraries-development/ documents/sdgs-insert.pdf.

Kementerian PPN-Bappenas. 2017. Tentang SDGs. http://sdgs.bappenas.go.id/tentang.

Kementerian PPN-Bappenas. 2017. Apa Itu SDGs? SDGs Indonesia. http://sdgs.bappenas.go.id/tentang/.

Mansour, E. 2019. Libraries as Agents for Development: The Potential Role of Egyptian Rural Public Libraries towards the Attainment of Sustainable Development Goals Based on the UN 2030 Agenda. Journal of Librarianship and Information Science, 52(1): 1-16. https://doi. org/10.1177/0961000619872064.

Maria, N.N, \& Chinemerem, A.N. 2019. Ensure Inclusive and Equitable Quality Education and Promote Lifelong Learning Opportunities for Achieving Sustainable Development Goals: The Role of Libraries. International Journal of Library and Information Science Studies, 5: 30-35.

Okuonghae, O. \& Igbinovia, M.O. 2019. The Role of Academic Libraries towards the Attainment of Sustainable Development Goals: The Nigerian Perspective, Covenant Journal of Library and Information Science, 2(2): 51-68.

Olsen, H. 2003. Pendidikan Inklusif Suatu Strategi Menuju Pendidikan untuk Semua. Mataram: Direktorat PSLB.

Palinkas, L.A., Horwitz, S.M., Green, C.A., Wisdom, J.P., Duan, N., \& Hoagwood, K. 2015. Purposeful Sampling for Qualitative Data Collection and Analysis in Mixed Method Implementation Research. Administration and Policy in Mental Health and Mental Health Services Research, 42 (5): 533-44. https://doi.org/10.1007/s10488-013-0528-y.

Samantaray, M. 2017. Role of Libraries in Quality Education for Achieving SDG. Journal of Advances in Library and Information Science, 6: 31-35.

Silverman, D. 2016. Qualitative Research. London: SAGE Publications.

Susanti, D.A. 2019. Implementasi Konsep Inklusi Sosial di Perguruan Tinggi; Sebuah Wacana. Media Pustakawan, 26(3): 224-32.

Sustainable Development Solutions Network (SDSN), A. 2017. Getting Started with the SDGS in Universities. In Sustainable Development Solutions Network (SDSN) - Australia/Pacific in collaboration with the Australasian Campuses Towards Sustainability (ACTS) and the global SDSN Secretariat, 1-52.

The Global Goals for Sustainable Development. n.d. Icon Grid. The Global Goals for Sustainable Development. https://www.globalgoals.org/resources.

United-Nations. 2015. Sustainable Development Goals (SDGs) and Disability. un.org/development/desa/ disabilites/about-us/sustainable-development-goals-sdgs-and-disability-html. 